\title{
Protective effect of Lactobacillus plantarum ATCC8014 on acrylamide-induced oxidative damage in rats
}

\author{
Sijia Zhao ${ }^{1,2+}$, Xiaoduo Zhao ${ }^{1,2 \dagger}$, Qingbo Liu ${ }^{1,2}$, Yujun Jiang ${ }^{1,2}$, Yanhua Li ${ }^{3}$, Wenxiao Feng ${ }^{1,2}$, Honghua Xu ${ }^{1,2^{*}}$ \\ and Meili Shao ${ }^{1,2^{*}}$ (1)
}

\begin{abstract}
Acrylamide (AA), which is mainly found in fried foods, causes neurotoxicity, genetic toxicity, carcinogenic effects, and DNA damage. This study confirms that a strain of lactic acid bacteria (Lactobacillus plantarum ATCC8014) could alleviate the toxicity of rats by inhibiting the AA-induced oxidative damage. Forty-eight adult male SD rats were randomly divided into eight groups: control group, AA group (40 mg/kg), three different doses $\left(1 \times 10^{7} \mathrm{CFU} / \mathrm{ml}, 1 \times 10^{8} \mathrm{CFU} /\right.$ $\mathrm{ml}, 1 \times 10^{9} \mathrm{CFU} / \mathrm{ml}$ of Lactobacillus plantarum ATCC8014) of prevention groups and therapeutic groups, respectively. At the end of three-week experiment, AA treatment produced a significant reduction in the rate of weight gain along with the symptoms of hind limb splay and ataxia. Histological examinations revealed various degrees of injury in five tissues. Levels of superoxide dismutase (SOD), catalase (CAT), and glutathione (GSH) in group AA rats were significantly decreased, but the level of lipid peroxidation (LPO) was significantly increased $(p<0.05)$. Both prevention and therapeutic groups with $1 \times 10^{9} \mathrm{CFU} / \mathrm{ml}$ of Lactobacillus plantarum ATCC8014 could effectively reduce the injury of AA to the body. However, reductions in both groups were not statistically significant.
\end{abstract}

Keywords: Acrylamide, Lactobacillus plantarum, Toxicity in vivo, Adsorption function, Antioxidant

\section{Introduction}

Acrylamide (AA) is a water-soluble vinyl monomer that is widely present in fried, baked, and roasted foods, such as French fries, breakfast cereals, and roasted coffee [1, 2]. In 2010 AA was classified as a Category 2 carcinogen and a Category 2 mutagen by the European Commission, as well as a substance of "very high concern" by the European Chemical Agency due to its neurotoxicity, genotoxicity, reproductive toxicity, and possible carcinogenicity [3]. Previous studies have mainly focused on the reduction of AA contents in foods by modifying the processing conditions $[4,5]$. However, the presence of AA in

\footnotetext{
*Correspondence: xhh3161@126.com; shml0915@163.com

†Sijia Zhao and Xiaoduo Zhao contributed equally to this work and should be considered co-first authors

2 Key Laboratory of Dairy Science, Ministry of Education, College of Food

Science, Northeast Agricultural University, Harbin 150030, China

Full list of author information is available at the end of the article
}

food remains unavoidable. Due to its high water solubility and low molecular weight, it can easily cross biological membranes, be absorbed in the gastrointestinal tract, and distributed throughout the body [6]. Several studies have shown that AA exposure could cause dyskinesia [7], growth retardation [8], energy metabolism disorders [9, 10], and genetic damage to germ cells in animals [11]. These symptoms were caused by exposure to AA, which can lead to imbalance in oxidant and antioxidant levels in vivo and to oxidative stress resulting from excessive production of reactive oxygen species (ROS) [12, 13]. Therefore, it is necessary to look for the strategies to reduce the toxicity in vivo by inhibiting the AA-induced oxidative damage.

In recent years, various biotechnology approaches have been used in order to cut down the contents and bioavailabilities of toxic and harmful substances [14, 15]. Lactic acid bacteria (LAB) strains, regarded as safe and 
environmentally-friendly substances, have been shown to have a slight detoxification effect, which has caught people's attention [16]. Several studies have shown that LAB strains have the ability to bind some carcinogens, including patulin, ochratoxin $A$, fumonisin $B_{1}$ and aflatoxins $\left(M_{1}, M_{2}\right.$, and $\left.B_{1}\right)$ in vitro [1, 16-19], and $L A B$ strains could also inhibit toxicity by adsorbing aflatoxin and Cadmium in vivo [20,21]. However, current research on LAB strains adsorbing AA is limited to in vitro experiments, and there is no data to confirm that it can alleviate AA toxicity in vivo. Studies have shown that peptidoglycan (PGN) on the cell walls of LAB strains is the main site for binding the toxicants. Differences in the composition of PGN and the cross-linking mode of PGN-linked peptides of different bacterial species affect the adsorption capacity of the LAB strains [22-24]. In our previous study, we screened five strains of LAB to explore the stability and mechanism of AA adsorption, and confirmed that Lactobacillus plantarum ATCC8014 (L. plantarum ATCC8014) has the best adsorption rate of $93.16 \%$ and optimal adsorption stability. In addition, the $\mathrm{C}=\mathrm{O}, \mathrm{C}-\mathrm{O}$, and $\mathrm{N}-\mathrm{H}$ groups in the cell wall are the primary functional groups for L. plantarum ATCC8014 to adsorb AA, and the adsorption capacity is related to cell wall roughness [25]. Moreover, Lactobacillus plantarum (L. plantarum) also has a well-known antioxidant function [26, 27]. We hypothesized that it could have the effect of alleviating the toxicity of AA in vivo. Therefore, the aim of this study was to explore the protective effect of L. plantarum ATCC8014 on the AA-induced toxicity in rats and its possible mechanism.

\section{Materials and methods Material and kits}

AA (99\% purity) was purchased from Beijing Boaotuo Co., Ltd (Beijing, China). Bicinchoninic acid (BCA) protein assay, superoxide dismutase (SOD) assay, catalase (CAT) assay, glutathione (GSH) assay, and lipid peroxidation (LPO) assay kits were purchased from Jiancheng Bioengineering Institute (Nanjing, China). AA was dissolved in physiological saline before administration to rats. All other chemicals and reagents employed in this work were of analytical grade and acquired from commercial sources.

\section{Preparation of AA solution}

The purchased AA was stored in a dry and ventilated place. In the first 5 days of the experiment, $0.8 \mathrm{~g}$ of AA was weighed and dissolved in $100 \mathrm{ml}$ of water before being administered to the rats every day. After weighing the rats' weight on the 6th, 11th and 16th day of the experiment, we adjust the amount of AA weighing according to the average value of rats' weight in each group, so as to ensure that the intragastric dose of rats is $40 \mathrm{mg} / \mathrm{kg} /$ day.

\section{Bacterial strains and culture}

Lactobacillus plantarum ATCC8014 was provided by College of Food Science, Northeast Agricultural University (Harbin, China). The strain was activated in MRS broth. Two sub-cultures were performed to determine the opportune cell concentrations before each experiment. Then, $4 \%$ of the LAB strains inocula was added to the MRS broth for $24 \mathrm{~h}$ at $37^{\circ} \mathrm{C}$. Bacterial cells were collected by centrifugation $\left(4{ }^{\circ} \mathrm{C}, 8000 \mathrm{r} / \mathrm{min}, 10 \mathrm{~min}\right)$ and then washed twice $10 \mathrm{~g} / \mathrm{L}$ sterilized peptone aqueous solution. After washing, $1 \mathrm{~g}$ of bacterial cells were added to the protective agent prepared with $12 \%$ defatted milk powder, $2 \%$ sucrose and $2 \%$ trehalose in $10 \mathrm{~mL}$ and mixed in ice water. The $\mathrm{pH}$ of bacterial suspension was adjusted to 7.0 with sterile sodium hydroxide. The amount of LAB strains was determined by plate count. Bacterial suspension was freeze-dried to make active powder and stored in the refrigerator at $-20{ }^{\circ} \mathrm{C}$. Before gavage, the concentration of $\mathrm{LAB}$ strains bacterial suspension was adjusted to $1 \times 10^{9} \mathrm{CFU} / \mathrm{ml}, 1 \times 10^{8} \mathrm{CFU} / \mathrm{ml}$ and $1 \times 10^{7} \mathrm{CFU} / \mathrm{ml}$, respectively.

\section{Experimental design}

Healthy male SD rats weighing $200 \pm 20$ g were purchased from the Laboratory Animal Department of Harbin Medical University (animal license number: SCXK 2013-001). The experimental protocol was approved by the Northeast Agricultural University Ethical Committee (China). Care and handling of the animals were in accordance with the national animal research guidelines (Approved by the State Council on October 31, 1988, and promulgated by Decree No. 2 of the State Science and Technology Commission on November 14, 1988). Rats were housed in a well-ventilated room with controlled temperature $\left(20-24{ }^{\circ} \mathrm{C}\right)$ and humidity $(40-50 \%)$ and a $12 \mathrm{~h}$ light/dark cycle. Rats were allowed to adapt to their surroundings for 7 days prior to initiating experiments. Rats were given food and water ad libitum throughout the course of the study.

The freeze-dried bacterial powder was dissolved in distilled water and orally administered to each rat for 21 days. L. plantarum ATCC8014 was administered $1 \mathrm{~h}$ before or after AA exposure as preventive groups and therapeutic groups, respectively.

A total of 48 healthy adult male rats were randomly divided into eight groups:

GroupI: Control group $(n=6)$, treated orally with physiological saline.

GroupII: AA group $(\mathrm{n}=6)$, administered $40 \mathrm{mg} / \mathrm{kg} /$ day AA by gastric gavage. 
GroupIII: Low dose prevention group $(\mathrm{n}=6), 1 \mathrm{~h}$ before AA administration ( $40 \mathrm{mg} / \mathrm{kg} /$ day), $1 \times 10^{7} \mathrm{CFU} /$ $\mathrm{ml}$ L. plantarum ATCC8014 $(1 \mathrm{ml})$ was given by gastric gavage.

GroupIV: Medium dose prevention group $(\mathrm{n}=6), 1 \mathrm{~h}$ before AA administration ( $40 \mathrm{mg} / \mathrm{kg} /$ day), $1 \times 10^{8} \mathrm{CFU} /$ $\mathrm{ml}$ L. plantarum ATCC $8014(1 \mathrm{ml})$ was given by gastric gavage.

GroupV: High dose prevention group $(\mathrm{n}=6), 1 \mathrm{~h}$ before AA administration $\left(40 \mathrm{mg} / \mathrm{kg} /\right.$ day), $1 \times 10^{9} \mathrm{CFU} / \mathrm{ml} L$. plantarum ATCC8014 (1 ml) was given by gastric gavage.

GroupVI: Low dose therapeutic group $(\mathrm{n}=6), 1 \mathrm{~h}$ after AA administration $\left(40 \mathrm{mg} / \mathrm{kg} /\right.$ day), $1 \times 10^{7} \mathrm{CFU} / \mathrm{ml} L$. plantarum ATCC8014 (1 ml) was given by gastric gavage.

GroupVII: Medium dose therapeutic group $(n=6), 1 \mathrm{~h}$ after AA administration ( $40 \mathrm{mg} / \mathrm{kg} /$ day), $1 \times 10^{8} \mathrm{CFU} /$ $\mathrm{ml}$ L. plantarum ATCC8014 $(1 \mathrm{ml})$ was given by gastric gavage.

GroupVIII: High dose therapeutic group $(\mathrm{n}=6), 1 \mathrm{~h}$ after AA administration ( $40 \mathrm{mg} / \mathrm{kg} /$ day), $1 \times 10^{9} \mathrm{CFU} /$ $\mathrm{ml}$ L. plantarum ATCC8014 $(1 \mathrm{ml})$ was given by gastric gavage.

During the 21 days of intervention, body weight, gait scores and hind limb splay were measured every 5 days.

\section{Behavioral analyses \\ Gait scores test}

Gait scores were measured every 5 days. To observe gait abnormalities, rats were placed in a clear box and were observed for $3 \mathrm{~min}$, and a gait score was assigned from 1 to 4 according to the criteria of numerical gait score, i.e., 1 (unaffected $)=$ a normal gait; 2 (slightly affected $)=a$ slightly abnormal gait (slight ataxia, hopping gait and foot splay); 3 (moderately affected)= moderately abnormal gait (obvious ataxia and foot splay with limb abduction during ambulation); 4 (severely affected)= severely abnormal gait (inability to support body weight and foot splay).

\section{Hind limb splay examination}

To assess hind limb splay, the hind feet of rats were inked and were held in a horizontal position $32 \mathrm{~cm}$ above white paper. Rats were then dropped onto the paper and the distance between the center of the right and left heels was measured. The hind limb heel prints were recorded three times for each rat. The mean values were then calculated for individual rats.

\section{Collection of tissue samples}

$24 \mathrm{~h}$ after the final treatment, after ether anesthesia, animals were sacrificed of cervical dislocation and their tissues (hippocampus, cerebellum, liver, small intestine, kidney) were collected. One part of each tissue was fixed in $4 \%$ paraformaldehyde for histopathological observation; the other part was stored at $-80{ }^{\circ} \mathrm{C}$ until oxidative stress indicators were detected.

\section{Determination of oxidative stress parameters}

After washing hair and blood stains in sterile saline, we weighed $0.1 \mathrm{~g}$ hippocampus, cerebellum, liver, ileum part of small intestine and kidney, homogenized them in saline to obtain $10 \%$ homogenate $(\mathrm{w} / \mathrm{v})$. The supernatant was obtained after centrifugation $(2500 \mathrm{r} / \mathrm{min}$, for $10 \mathrm{~min}$ ). Next, the activities of SOD, CAT, GSH, and the level of LPO were determined according to the kit instructions.

\section{Histopathological analysis}

Hippocampus, cerebellum, liver, small intestine, kidney tissues of dissected rats were collected and fixed in $4 \%$ paraformaldehyde solution. Then, these tissues analysed based on histological tissue follow-up procedures and embedded in paraffin blocks. After the cutting of $5 \mu \mathrm{m}$ thick paraffin sections, hematoxylin-eosin staining was performed. Then, the histological slides were examined by light microscopy.

\section{Statistical analysis}

Analysis of data was performed using the computer program SPSS 23.0 for Windows. The data were analyzed by ANOVA and post hoc analysis of group differences was performed by the LSD test. Each experiment was repeated three times and the results were given as the mean \pm standard deviation. The statistically significance was considered as $\mathrm{p}<0.05$.

\section{Results}

\section{Effects on body weight}

As shown in Fig. 1, there was no significant difference in the starting body weight among the eight groups of rats $(p>0.05)$. Body weight increased in each group of rats over the 21-day course of the study, with the weight gain of control rats increasing by $61.57 \%$. Rats in the AA group grew slowly, with a body weight gain rate of $15.99 \%$. From the sixth day on, the body weight in the AA group was significantly lower than that of the control group $(\mathrm{p}<0.05)$. Compared to the control group, the weight gain of rats treated with a high dose of L. plantarum ATCC8014 $\left(1 \times 10^{9} \mathrm{CFU} / \mathrm{ml}\right)$ was the greatest significantly higher than the weight gain of the rats in the middle and low dose groups.

\section{Effects on hind limb splay}

As shown in Fig. 2, at the beginning of AA exposure, rats exhibited a normal degree of hind limb splay. Except for the control group, the hind limb splay in 


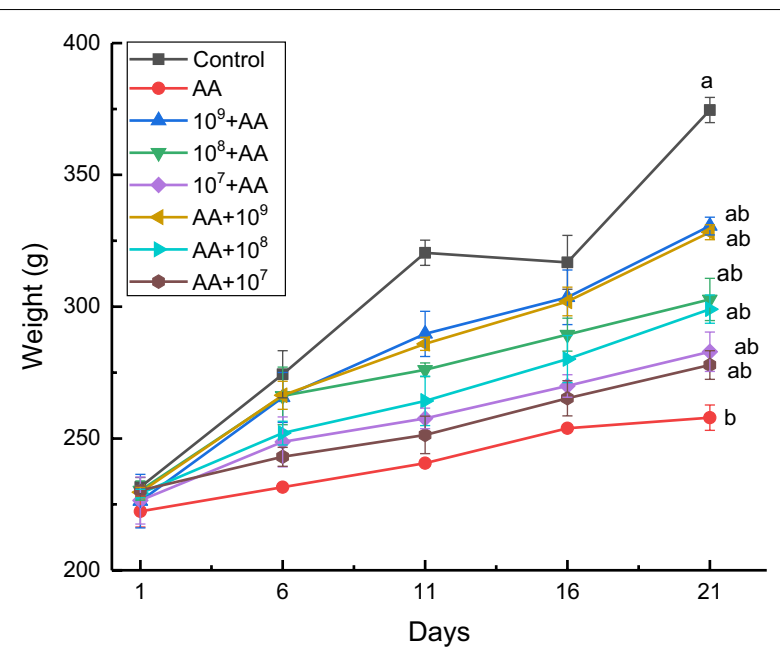

Fig. 1 Weight changes. Effect of the weight changes in different groups. Values are expressed as mean $\pm S D$, for 6 animals in each group. "a" values differ significantly from AA group at the 21 st day, no labeling represents no significant difference $(p<0.05)$; " $b$ " values differ significantly from control group at the 21 st day, no labeling represents no significant difference $(p<0.05)$

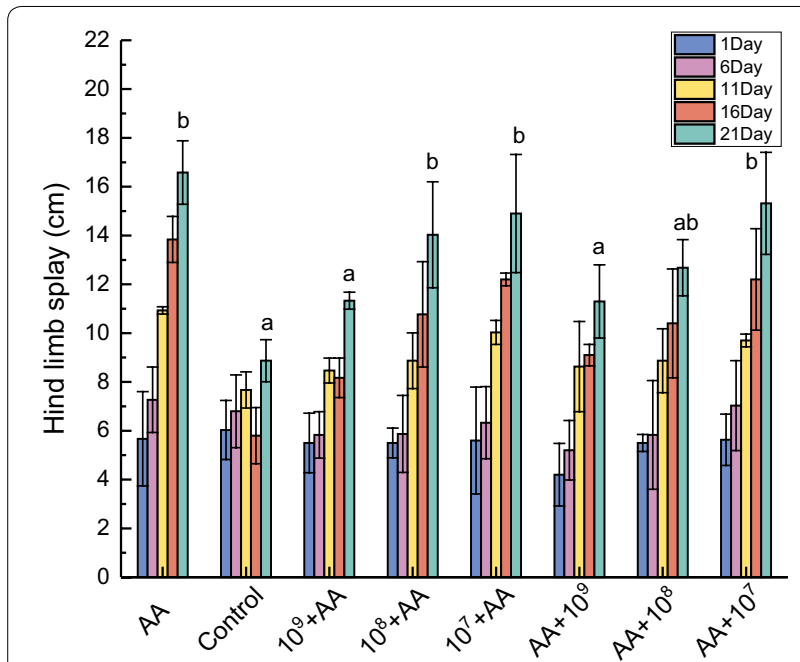

Fig. 2 Hind limb splay. Effect of the hind limb splay in different groups. Values are expressed as mean \pm SD, for 6 animals in each group. "a" values differ significantly from AA group at the 21st day, no labeling represents no significant difference $(p<0.05)$; " $b$ " values differ significantly from control group at the 21 st day, no labeling represents no significant difference $(p<0.05)$

each group continued to increase with ongoing exposure. After 21 days, the hind limb splay in the AA group increased from $5.67 \pm 1.93 \mathrm{~cm}$ to $16.58 \pm 1.30 \mathrm{~cm}$. The hind limb splay of rats in high dose groups were significantly shorter $(\mathrm{p}<0.05)$ than that of rats in the AA group and the low dose groups, and there was no significant difference between the high dose group and the control group ( $p>0.05$ ). The hind limb splay in low dose groups were was close to that in the AA group. In this study, there was no significant difference in hind limb splay between the therapeutic group and the prevention group treated with the same dose of L. plantarum ATCC8014 $(p>0.05)$. (Additional file 1 shows the appearance of each group of rats on the last day of the experiment).

\section{Effects on gait change}

As shown in Fig. 3, 21 days of exposure to AA can induce progressive gait abnormalities in rats, characterized by an unsteady walking pattern with abduction and external rotation of the hind limbs, increased heel splay and decreased locomotor activity. In the AA group, gait scores increased from an initial $1.00 \pm 0.00$ (normal gait) to $4.00 \pm 0.00$ by the end of the 21-day exposure period. The treatment of L. plantarum ATCC8014 with low, medium and high dose had certain protective effects on gait abnormality in rats. The high dose group had the best results in alleviating abnormal gait. In addition, there was no significant difference on gait change between the therapeutic group and the prevention group treated with the same dose of L. plantarum ATCC8014 ( $>0.05)$.

\section{Effects on oxidative stress parameters}

Enzyme activities of SOD and CAT, and levels of LPO and GSH in tissue samples from the hippocampus, cerebellum, liver, small intestine, and kidneys are provided

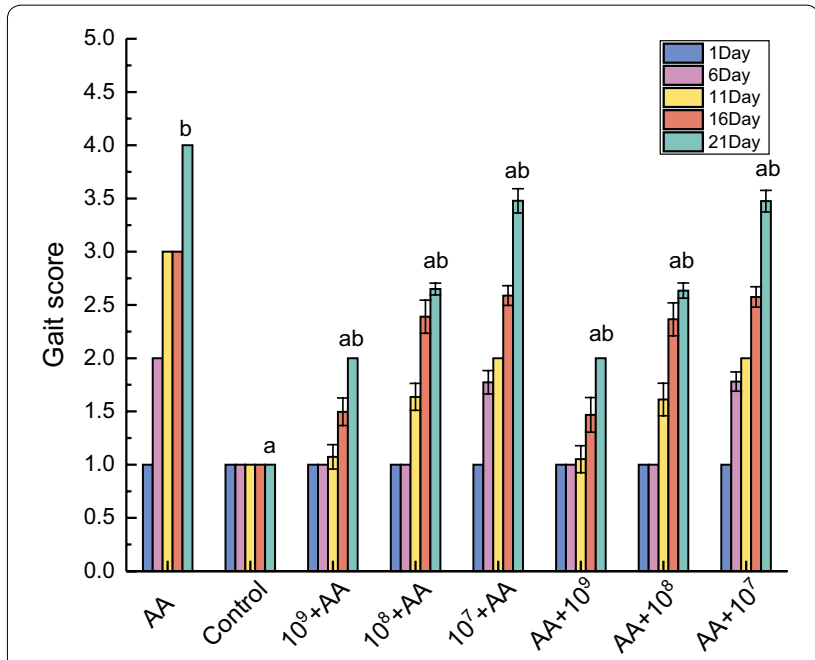

Fig. 3 Gait score. Effect of the gait score in different groups. Values are expressed as mean \pm SD, for 6 animals in each group. "a" values differ significantly from AA group at the 21st day, no labeling represents no significant difference $(p<0.05)$; "b" values differ significantly from control group at the 21 st day, no labeling represents no significant difference $(p<0.05)$ 
Table 1 Effects of AA and three different doses Lactobacillus plantarum ATCC8014 of prevention groups and therapeutic groups on oxidative stress parameters in 5 tissues of rats

\begin{tabular}{|c|c|c|c|c|c|c|}
\hline & Treatment design & Hippocampus & Cerebellar & Liver & Small intestine & Kidney \\
\hline \multirow[t]{8}{*}{ LPO ( $\mu \mathrm{mol} / \mathrm{gprot})$} & Control & $24.17 \pm 1.93^{\mathrm{a}}$ & $14.04 \pm 1.57^{\mathrm{a}}$ & $17.51 \pm 3.35^{\mathrm{a}}$ & $34.54 \pm 5.43^{\mathrm{a}}$ & $34.80 \pm 1.23^{\mathrm{a}}$ \\
\hline & $\mathrm{AA}$ & $48.18 \pm 3.85^{b}$ & $52.22 \pm 4.33^{b}$ & $43.76 \pm 2.68^{b}$ & $70.89 \pm 3.22^{b}$ & $83.29 \pm 4.20^{b}$ \\
\hline & $10^{9}+\mathrm{AA}$ & $21.89 \pm 2.03^{\mathrm{a}}$ & $29.46 \pm 3.21^{\mathrm{ab}}$ & $22.40 \pm 2.11^{\mathrm{a}}$ & $38.71 \pm 3.78^{a}$ & $59.89 \pm 5.32^{\mathrm{a}}$ \\
\hline & $10^{8}+\mathrm{AA}$ & $27.36 \pm 1.24^{\mathrm{a}}$ & $33.48 \pm 2.8^{\mathrm{ab}}$ & $24.10 \pm 2.34^{\mathrm{a}}$ & $44.15 \pm 3.13^{\mathrm{a}}$ & $62.97 \pm 2.33^{\mathrm{a}}$ \\
\hline & $10^{7}+\mathrm{AA}$ & $30.04 \pm 1.94^{\mathrm{a}}$ & $43.78 \pm 1.76^{b}$ & $33.51 \pm 3.06^{\mathrm{ab}}$ & $54.12 \pm 4.41^{\mathrm{ab}}$ & $67.16 \pm 4.58^{\mathrm{a}}$ \\
\hline & $A A+10^{9}$ & $31.20 \pm 3.91^{\mathrm{ab}}$ & $27.90 \pm 1.23^{\mathrm{ab}}$ & $20.55 \pm 1.61^{\mathrm{a}}$ & $39.02 \pm 4.35^{\mathrm{a}}$ & $44.38 \pm 2.44^{\mathrm{a}}$ \\
\hline & $\mathrm{AA}+10^{8}$ & $40.02 \pm 3.52^{a b}$ & $36.38 \pm 2.81^{\mathrm{ab}}$ & $24.82 \pm 1.31^{\mathrm{a}}$ & $44.48 \pm 1.46^{\mathrm{ab}}$ & $44.58 \pm 2.67^{a}$ \\
\hline & $A A+10^{7}$ & $44.39 \pm 3.51^{b}$ & $46.41 \pm 2.34^{b}$ & $33.84 \pm 1.07^{\mathrm{ab}}$ & $59.67 \pm 3.26^{\mathrm{ab}}$ & $63.78 \pm 4.03^{\mathrm{a}}$ \\
\hline \multirow[t]{8}{*}{ GSH (mg/gprot) } & Control & $7.77 \pm 0.45^{\mathrm{a}}$ & $13.76 \pm 1.08^{\mathrm{a}}$ & $9.88 \pm 0.59^{a}$ & $7.13 \pm 0.14^{\mathrm{a}}$ & $12.20 \pm 0.50^{\mathrm{a}}$ \\
\hline & AA & $3.84 \pm 0.41^{b}$ & $9.81 \pm 0.83^{b}$ & $3.25 \pm 0.67^{b}$ & $4.45 \pm 0.33^{b}$ & $6.45 \pm 0.27^{b}$ \\
\hline & $10^{9}+\mathrm{AA}$ & $7.30 \pm 0.31^{\mathrm{a}}$ & $13.55 \pm 1.39^{\mathrm{a}}$ & $6.89 \pm 0.71^{\mathrm{ab}}$ & $5.96 \pm 0.31^{\mathrm{ab}}$ & $10.96 \pm 0.57^{a}$ \\
\hline & $10^{8}+\mathrm{AA}$ & $6.65 \pm 0.35^{\mathrm{a}}$ & $11.19 \pm 1.10^{b}$ & $4.92 \pm 0.06^{\mathrm{ab}}$ & $5.27 \pm 0.28^{\mathrm{ab}}$ & $10.31 \pm 0.37^{\mathrm{a}}$ \\
\hline & $10^{7}+\mathrm{AA}$ & $6.45 \pm 0.28^{\mathrm{a}}$ & $10.71 \pm 0.85^{b}$ & $4.52 \pm 0.21^{\mathrm{ab}}$ & $4.69 \pm 0.26^{b}$ & $8.71 \pm 0.51^{\mathrm{ab}}$ \\
\hline & $A A+10^{9}$ & $7.28 \pm 0.40^{\mathrm{a}}$ & $11.86 \pm 1.06^{\mathrm{a}}$ & $6.74 \pm 0.23^{\mathrm{a}}$ & $6.20 \pm 0.33^{\mathrm{ab}}$ & $10.85 \pm 0.11^{\mathrm{ab}}$ \\
\hline & $\mathrm{AA}+10^{8}$ & $6.26 \pm 0.24^{\mathrm{a}}$ & $11.14 \pm 0.22^{b}$ & $5.50 \pm 0.13^{a b}$ & $6.07 \pm 0.26^{\mathrm{ab}}$ & $8.76 \pm 0.15^{\mathrm{ab}}$ \\
\hline & $A A+10^{7}$ & $5.99 \pm 0.37^{\mathrm{a}}$ & $10.32 \pm 1.16^{b}$ & $5.00 \pm 0.34^{a b}$ & $5.70 \pm 0.19^{a}$ & $7.78 \pm 0.58^{\mathrm{ab}}$ \\
\hline \multirow[t]{8}{*}{ SOD (U/mgprot) } & Control & $49.33 \pm 0.89^{a}$ & $69.07 \pm 0.82^{\mathrm{a}}$ & $15.10 \pm 0.40^{\mathrm{a}}$ & $36.50 \pm 0.63^{a}$ & $17.96 \pm 0.67^{\mathrm{a}}$ \\
\hline & AA & $33.53 \pm 0.77^{b}$ & $37.96 \pm 0.67^{b}$ & $9.67 \pm 0.29^{b}$ & $17.60 \pm 0.63^{b}$ & $15.86 \pm 0.75^{b}$ \\
\hline & $10^{9}+\mathrm{AA}$ & $43.37 \pm 0.85^{\mathrm{a}}$ & $60.91 \pm 0.75^{\mathrm{ab}}$ & $13.26 \pm 0.65^{\mathrm{a}}$ & $29.80 \pm 0.92^{\mathrm{ab}}$ & $13.30 \pm 0.36^{\mathrm{a}}$ \\
\hline & $10^{8}+\mathrm{AA}$ & $39.74 \pm 0.83^{a b}$ & $55.70 \pm 0.87^{a b}$ & $12.31 \pm 0.54^{\mathrm{ab}}$ & $27.76 \pm 0.72^{\mathrm{ab}}$ & $15.93 \pm 0.53^{\mathrm{ab}}$ \\
\hline & $10^{7}+A A$ & $37.18 \pm 0.99^{b}$ & $51.50 \pm 0.59^{b}$ & $10.59 \pm 0.53^{\mathrm{ab}}$ & $25.30 \pm 0.68^{b}$ & $14.48 \pm 0.72^{b}$ \\
\hline & $A A+10^{9}$ & $42.67 \pm 0.86^{\mathrm{ab}}$ & $60.44 \pm 0.91^{\mathrm{a}}$ & $12.66 \pm 0.63^{\mathrm{a}}$ & $26.17 \pm 0.68^{a}$ & $12.78 \pm 0.54^{\mathrm{ab}}$ \\
\hline & $\mathrm{AA}+10^{8}$ & $38.97 \pm 0.84^{b}$ & $53.94 \pm 0.92^{\mathrm{ab}}$ & $11.53 \pm 0.47^{\mathrm{a}}$ & $23.30 \pm 0.70^{\mathrm{ab}}$ & $11.33 \pm 0.60^{\mathrm{ab}}$ \\
\hline & $A A+10^{7}$ & $36.68 \pm 0.74^{b}$ & $46.80 \pm 1.02^{\mathrm{ab}}$ & $10.55 \pm 0.37^{a b}$ & $21.09 \pm 0.95^{b}$ & $23.37 \pm 0.70^{a b}$ \\
\hline \multirow[t]{8}{*}{ CAT (U/mgprot) } & Control & $31.97 \pm 1.16^{\mathrm{a}}$ & $73.83 \pm 0.74^{\mathrm{a}}$ & $12.19 \pm 0.73^{\mathrm{a}}$ & $24.50 \pm 0.84^{\mathrm{a}}$ & $13.16 \pm 0.83^{\mathrm{a}}$ \\
\hline & AA & $17.30 \pm 0.81^{b}$ & $25.88 \pm 0.87^{b}$ & $4.48 \pm 0.60^{b}$ & $8.92 \pm 0.51^{b}$ & $6.19 \pm 0.38^{b}$ \\
\hline & $10^{9}+\mathrm{AA}$ & $28.56 \pm 0.73^{\mathrm{a}}$ & $59.52 \pm 1.09^{\mathrm{a}}$ & $10.49 \pm 0.75^{\mathrm{ab}}$ & $23.17 \pm 0.75^{b}$ & $10.72 \pm 0.91^{\mathrm{ab}}$ \\
\hline & $10^{8}+\mathrm{AA}$ & $26.55 \pm 1.29^{\mathrm{a}}$ & $55.59 \pm 0.98^{\mathrm{a}}$ & $7.76 \pm 0.71^{\mathrm{ab}}$ & $15.15 \pm 0.62^{b}$ & $9.72 \pm 0.38^{\mathrm{ab}}$ \\
\hline & $10^{7}+\mathrm{AA}$ & $23.94 \pm 1.14^{\mathrm{ab}}$ & $47.60 \pm 1.31^{\mathrm{a}}$ & $6.66 \pm 0.48^{b}$ & $12.12 \pm 0.76^{\mathrm{ab}}$ & $8.94 \pm 0.58^{\mathrm{ab}}$ \\
\hline & $A A+10^{9}$ & $27.67 \pm 0.55^{\mathrm{a}}$ & $59.43 \pm 0.75^{a}$ & $9.59 \pm 0.74^{\mathrm{ab}}$ & $21.81 \pm 0.93^{a}$ & $10.49 \pm 0.32^{\mathrm{a}}$ \\
\hline & $A A+10^{8}$ & $24.67 \pm 0.66^{\mathrm{ab}}$ & $54.57 \pm 0.52^{\mathrm{a}}$ & $8.52 \pm 0.51^{\mathrm{ab}}$ & $15.02 \pm 0.61^{a}$ & $9.26 \pm 0.57^{a b}$ \\
\hline & $A A+10^{7}$ & $21.38 \pm 0.91^{a b}$ & $44.38 \pm 0.72^{b}$ & $5.53 \pm 0.52^{b}$ & $10.64 \pm 1.12^{\mathrm{a}}$ & $8.35 \pm 0.78^{\mathrm{ab}}$ \\
\hline
\end{tabular}

Values are expressed as mean \pm SD for 6 animals in each group. "a" values differ significantly from AA group $(p<0.05)$, no labeling represents no significant difference; " $b$ " values differ significantly from control group $(p<0.05)$, no labeling represents no significant difference

in Table 1. As expected, AA significantly reduced enzyme activities of SOD and CAT, as well as the level of GSH, and it induced an obvious increase in LPO levels, as evident in five tissue samples of the AA rats compared with those of the control rats $(\mathrm{p}<0.05)$. Both in the therapeutic groups and the prevention groups, the rats treated with L. plantarum ATCC8014 had an increase in SOD, CAT activity, and GSH content, while a decrease in the LPO content. Among these, the above parameters were significantly changed in rats treated with high doses of L. plantarum ATCC8014 compared to those of rats in the AA group $(\mathrm{p}<0.05)$.

\section{Effects on histopathology}

The hippocampus of the rats in the control group had a clear neuron structure and a certain number of glial cells. Compared with the control group, the hippocampus of the AA group showed degenerative changes, including pale staining or dissolution of nucleus of nerve cells, blurred neural cell structure, and increased number of glial cells showing diffuse proliferation. In the low dose $\left(1 \times 10^{7} \mathrm{CFU} / \mathrm{ml}\right.$ L. plantarum ATCC8014) therapeutic 
group and the prevention group, there was a slight sign of recovery in the hippocampus of the rats, but damage to the nerve cell structure and glial cells still existed. There was no obvious pathological change in the high dose group, and most neurons and glia were normal (Fig. 4).

In the control group, the structure of nerve cells in the cerebellum was clear, granular layer cells were abundant, and Purkinje cells were arranged neatly. The Purkinje cells in the AA group were smaller than those in the control group, showing obvious karyolysis, and the number of granular layer cells was significantly reduced. The protective effect of low dose L. plantarum ATCC8014 on AA-induced toxicity was weak but still better than that of the AA group. It showed that the number of Purkinje cells decreased, some cells dissolved, and the structure of cells was blurred. The protective effect of the high dose group was the strongest and without obvious pathological changes. There was no significant difference between the therapeutic group and the prevention group at the same dose (Fig. 5).
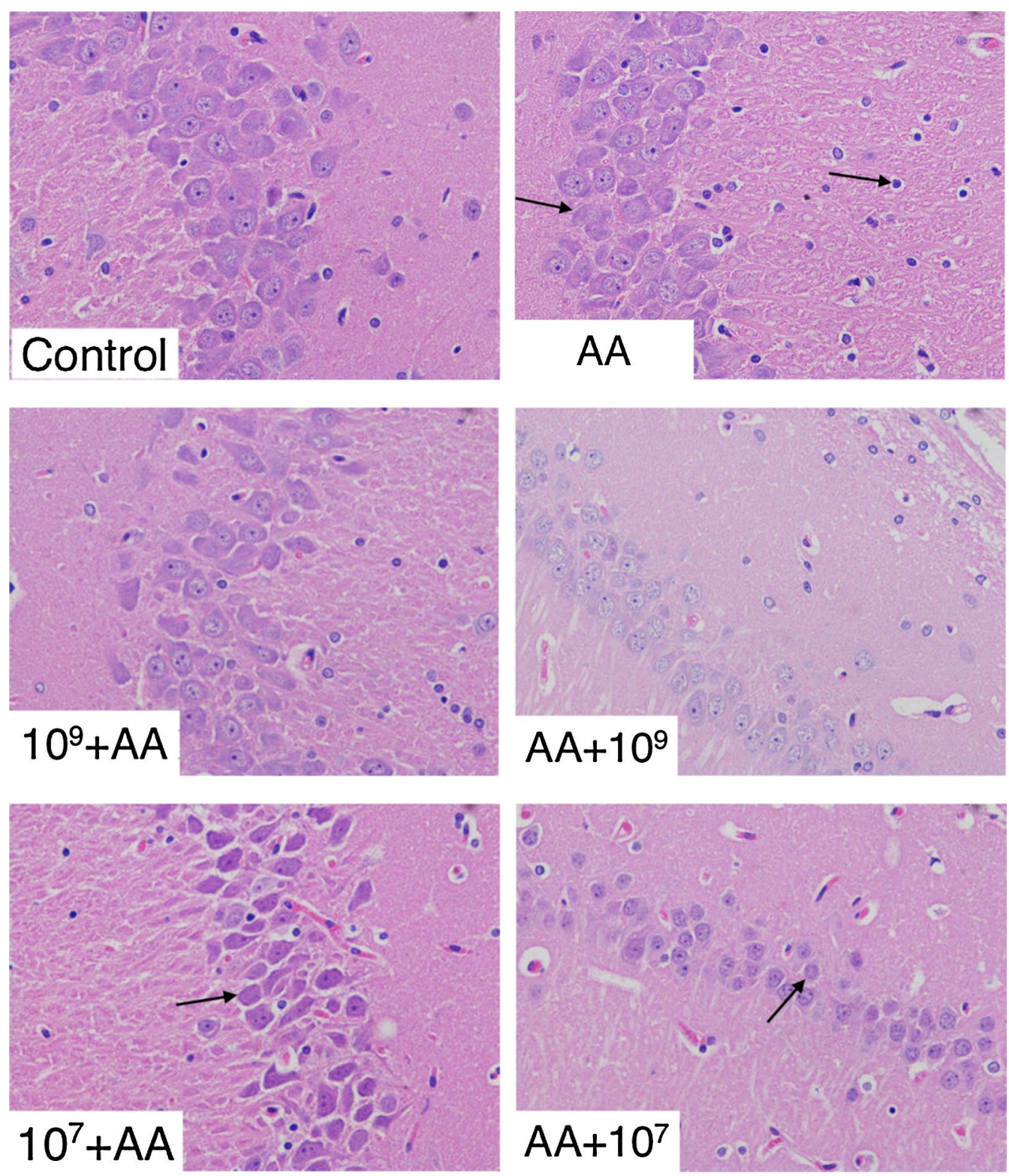

Fig. 4 Histopathological sections of hippocampus (H\&E ×400). Note: The control group showed evenly stained nerve cells, and nuclei were centrally located with clear nucleoli. The AA group and two low dose groups showed obvious nucleolysis and blurred cell structure, suggesting cell necrosis (black arrow) and increased glial cells. Nerve cell damage was not obvious in two high dose groups 

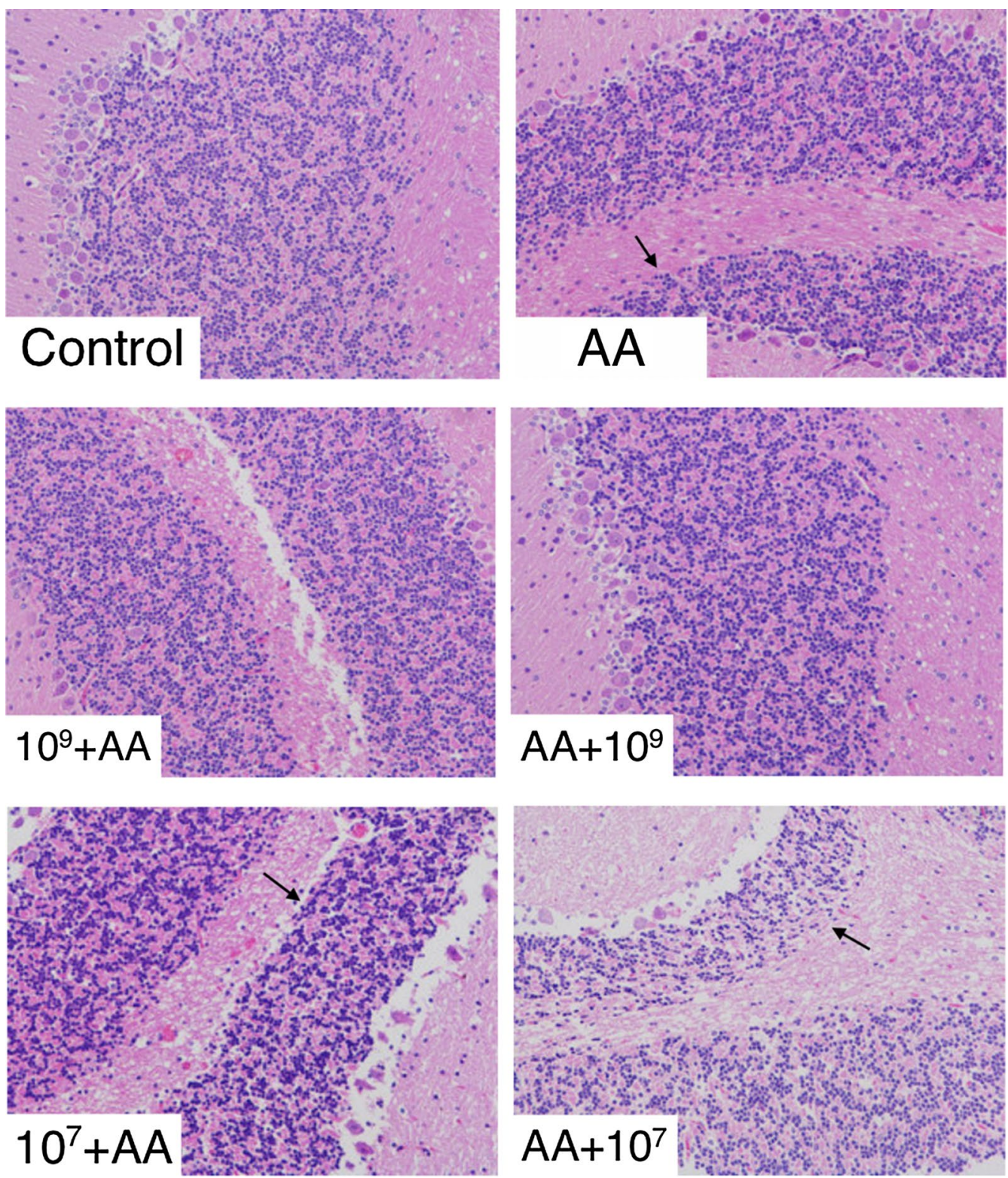

Fig. 5 Histopathological sections of cerebellum (H\&E × 200). Note: Control group showing regularly arranged Purkinkje cells and abundant granular cells. AA group and two low dose groups showed degenerated Purkinje cells with cavities around them. Granular cells were markedly diminished in number (black arrow).There were abundant granular layer cells and clear cell structure in two high dose groups

Liver sections of the rats in the control group had normal histological structure. Congestion in the central vein, sinusoidal, and vascular structures in the portal region were observed in the AA group liver sections. No striate arrangement of hepatocytes was found. In the low dose groups, there was no obvious strand arrangement of hepatocytes, and some nucleolysis, nuclear concentration, and a small amount of lymphocyte infiltration were observed. Compared with the low dose groups, the high dose groups improved these symptoms significantly (Fig. 6).

Mucus and the small intestinal villi of the rats in the control group were arranged regularly. In the AA group, there was an increase in necrosis and exfoliation of mucosal epithelial cells, intestinal villus rupture, vascular congestion, and lymphocyte lamina propria. The epithelial cells of intestinal mucosa of rats in low dose groups were exfoliated, but there was no obvious pathological change in the high dose groups. The protective 

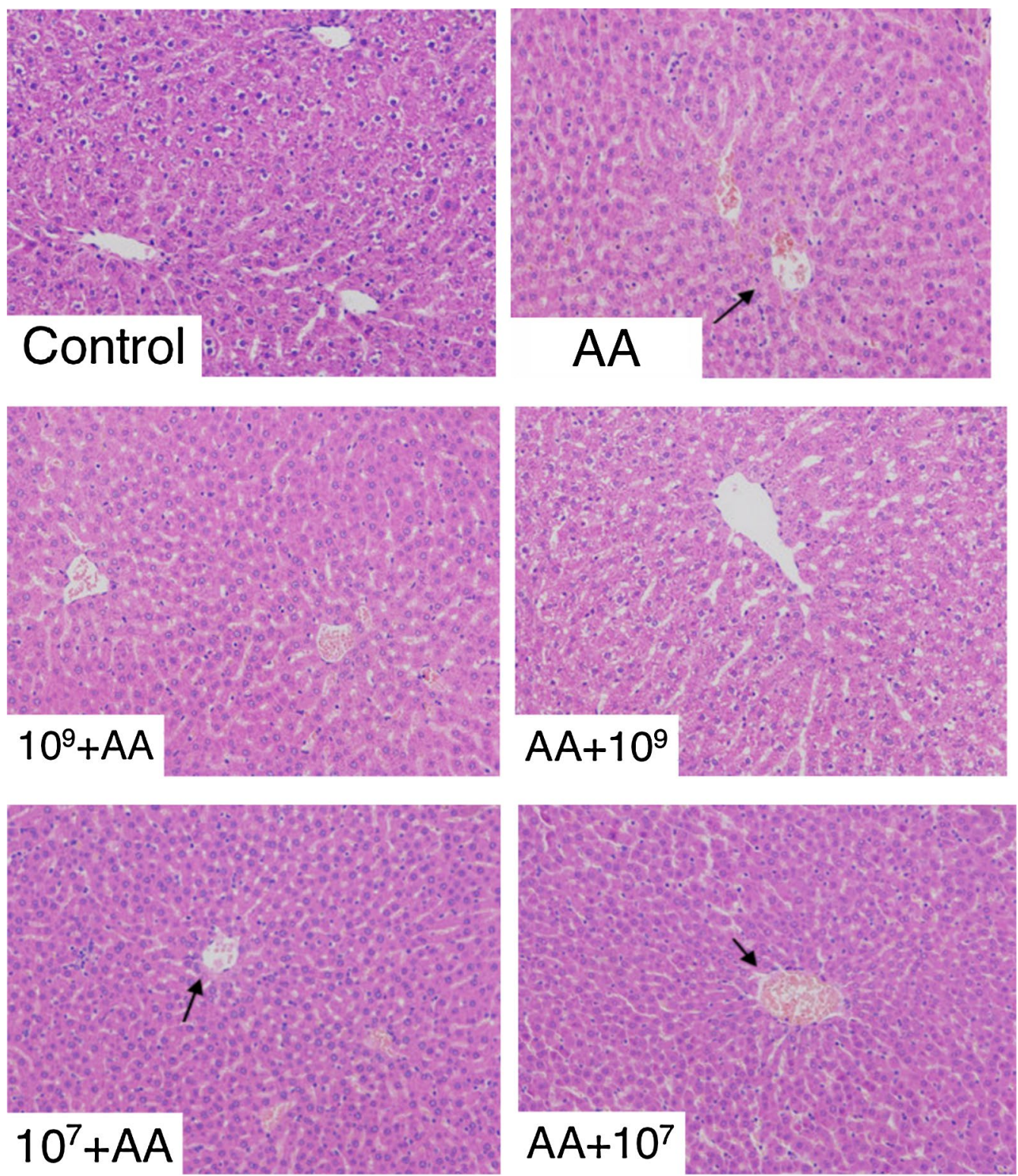

Fig. 6 Histopathological sections of liver (H\&E $\times 200)$. Sections from the control group showed cells arranged in strings with clear subcellular structure. The AA group and two low dose groups showed congestion of the central vein (black arrow), hepatocyte necrosis, and intracytoplasmic vacuoles. There was central venous congestion in the high dose prevention group, but no obvious pathological damage in the high dose therapeutic group

effect of low dose and high dose prevention groups on AA-induced injury was slightly better than that of the therapeutic groups (Fig. 7).

Figure 8 shows normal histological structure of glomeruli and surrounding tubules in the kidneys of control rats. The kidney tissue structure of rats treated with AA showed glomerular atrophy, the tubular epithelial cells became smaller, resulting in a thinner tubular wall, and part of the tubular epithelial cells were necrotic and shed. The protective effect of high dose L. plantarum ATCC8014 was significantly better than that of the low dose group, and no obvious pathological tissue damage was observed. 

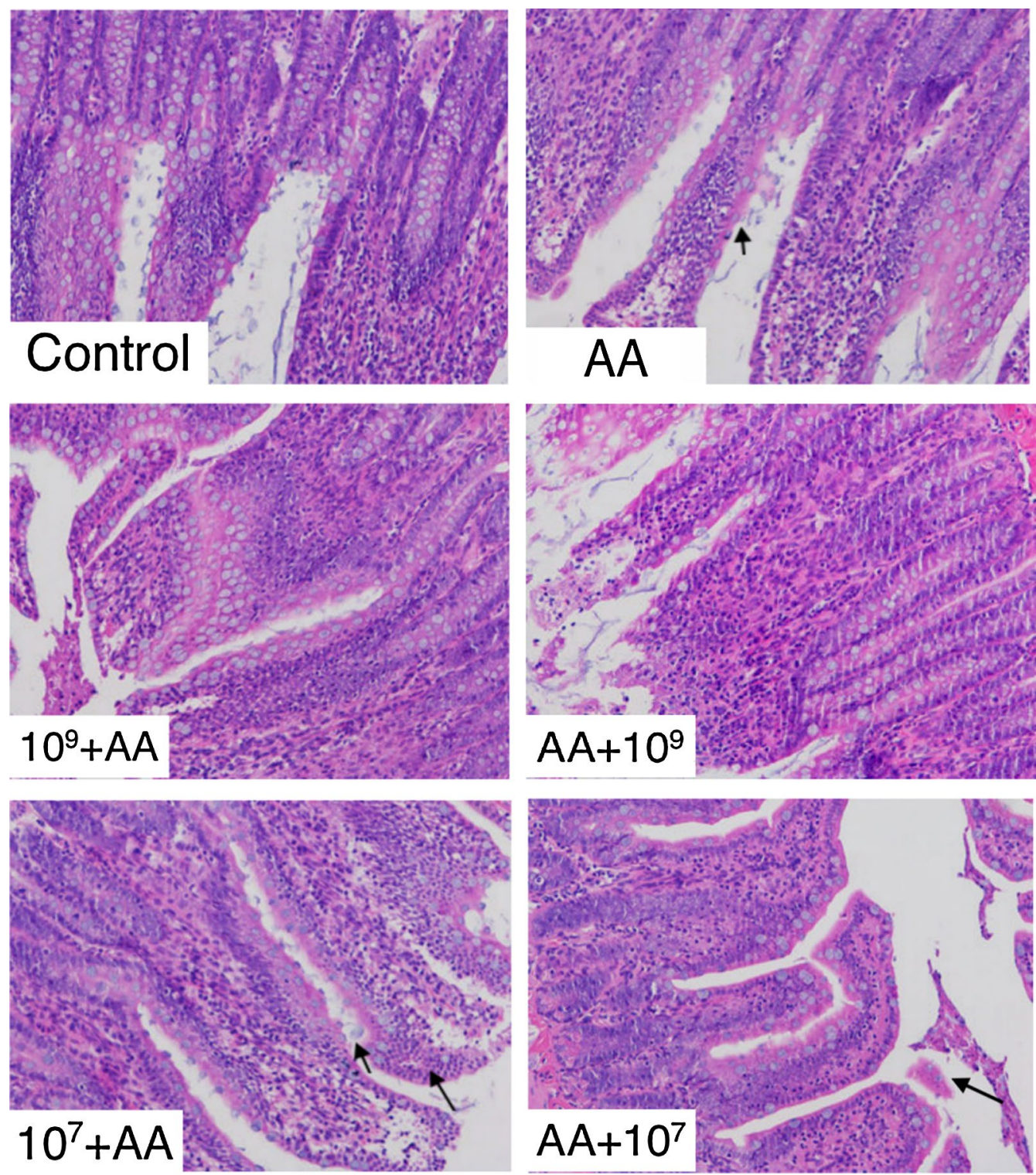

Fig. 7 Histopathological sections of small intestine $(H \& E \times 200)$. The control group showed clear villus structure. AA group and low dose prevention group showed intestinal villous epithelial cell exfoliation (black arrow). Low dose therapeutic group showed intestinal villus rupture. Two high dose groups showed slight intestinal villus rupture

\section{Discussion}

At present, most research focuses on reducing the production of AA in food by physical and chemical methods. However, current processing technologies cannot allow people a complete avoidance of AA. It is worth noting that there have been few studies on reducing toxicity in vivo after the AA intake. Therefore, we aimed to explore whether $L$. plantarum ATCC8014 can alleviate the oxidative stress induced by AA in rats. In addition, we set up the preventive groups and the therapeutic groups at the same time, aiming to preliminary explore whether the protective effect of $L$. plantarum ATCC8014 before or after the administration of AA was different. So as to lay the foundation for further study on $L$. plantarum ATCC8014 alleviating AA oxidative damage.

A large number of studies have proved that AA can cause severe damage to the antioxidant system of rats. Continuous exposure of AA leads to excessive production of reactive oxygen species (ROS) and exceeds the load of the antioxidant system $[12,13]$, resulting in 

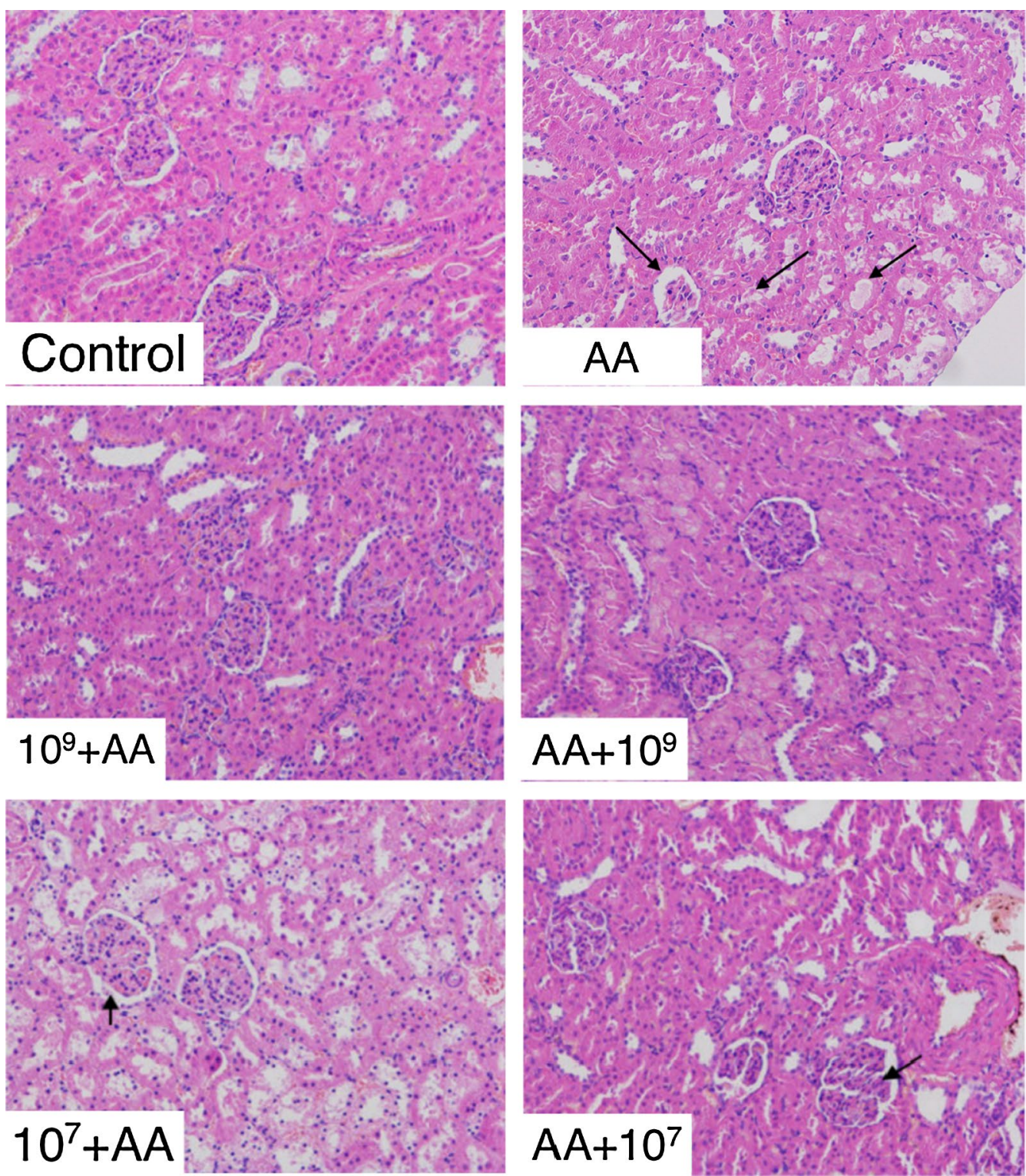

Fig. 8 Histopathological sections of kidneys $(H \& E \times 200)$. The control group showed normal histological structure of the glomeruli and surrounding tubules in the kidney. The AA group and two low dose groups showed glomerular atrophy, and enlarged bowman's space (black arrow). There was no obvious pathological damage in the two high dose groups

the collapse of the antioxidant system in rats, which is manifested by a sharp decrease in antioxidant enzyme (SOD, CAT) activity and the level of antioxidant (GSH) [28-30]. At this time, excessive ROS continuously attacked the cells, and the accumulation of lipid peroxides in the cells eventually caused oxidative damage to various tissues of the rats [31,32].

Many studies have shown that AA intake can cause slow growth or weight loss in rats [33,34]. According to our results, the body weight growth rate of rats in the high doses of $L$. plantarum ATCC8014 groups was significantly higher than that of the AA group, and lower than that of the control group, indicating that high doses of L. plantarum ATCC8014 can effectively alleviate the slow growth induced by AA in rats.

As a neurotoxic substance, AA damages both the central and peripheral nervous systems and causes rats adverse effects, such as ataxia, skeletal muscle weakness, and other abnormal behavior phenomena [33, 35]. Moreover, AA can reduce the levels of antioxidant enzymes 
(SOD, CAT) and GSH, and increase the level of LPO in rats [36, 37]. Our results showed that no obvious ataxia and hind limb valgus were observed in rats fed high doses of L. plantarum ATCC8014. Histopathological sections showed no obvious hippocampal neuron necrosis and Purkinje cell degeneration, and the number of cerebellar granular layer cells was significantly higher than that of the AA group, which further confirmed that L. plantarum ATCC8014 had a good mitigation effect on AAinduced nerve injury in rats. L. plantarum ATCC8014 could effectively enhance the activity of antioxidant enzymes and the level of GSH, and could enhance the antioxidant capacity of nerve tissue, thus preventing ROS from attacking cell membrane for a long time and reducing the accumulation of lipid peroxides. In addition, we hypothesized that $L$. plantarum ATCC8014 might improve the transmission of nerve interference signals and the interaction between nerve endings [38], and enhanced the activity of cholinesterase in the brain. As a potential marker, cholinesterase is thought to be involved in the regulation of cholinergic transmission, neurite growth and cell proliferation during the development of the nervous system [39].

When AA is absorbed from the intestine into the blood, it rapidly distributes into the liver, kidneys, and other tissues. Most of AA is metabolized to mercapturic acid in the liver with the help of GST/GSH system, filtered through the kidneys, and excreted from the body with urine $[40,41]$. Studies have shown that AA can damage liver, small intestine, kidneys and other tissues, mainly by inhibiting the levels of antioxidant enzymes SOD and CAT, reducing the level of GSH, increasing the accumulation of lipid peroxides, and ultimately causing tissue damage [31, 32, 42]. According to our experimental results, high dose of L. plantarum ATCC8014 could effectively improve the GSH level, as well as the SOD and CAT activity in the liver, small intestine, and kidneys of rats. In addition, it was evident that these three tissues of rats in the high dose group were only slightly damaged, and the degree of damage was much lighter than that of the rats in the AA group. Therefore, we hypothesized that L. plantarum ATCC8014 could help eliminate the excessive ROS caused by AA, maintain the balance of oxidants and antioxidants in rats, and reduce the damage caused by oxidative stress in vivo.

L. plantarum ATCC8014 could effectively alleviate AA - induced injuries in vivo for the following three potential reasons. First, L. plantarum ATCC8014 has a good adsorption effect on AA. Serrano-Nino et al. thought that carbonyl oxygen of AA might interact with glucose or glycerol hydroxyl in phosphoteichoic acid of LAB strains to stabilize its binding [15]. In addition, our previous studies have confirmed that the adsorption of AA by LAB strains is closely related to the properties of PGN and the adsorption capacity is related to the roughness of cell wall. $\mathrm{C}=\mathrm{O}, \mathrm{C}-\mathrm{O}$ and $\mathrm{N}-\mathrm{H}$ groups in $\mathrm{PGN}$, as the main binding sites, can effectively adsorb AA [25]. Therefore, we hypothesized that during the experiment part L. plantarum ATCC8014 would stay or colonize the intestinal tracts of rats and might combine with AA to form stable complexes. Research by Gratz et al. shows that complexes formed by Lactobacillus rhamnosus GG adsorbing aflatoxin $B_{1}$ are more likely to be excreted from the body through feces [43], so we hypothesized that L. plantarum ATCC8014-AA complexes might be excreted from the body rather than absorbed by the intestinal tract, reducing the absorption of AA and further alleviating the toxicity of AA in vivo. Second, many probiotics, including $L$. plantarum, protect the intestinal barrier by upregulating the expression of tight junction proteins [44, 45], and can even reduce the absorption of toxic substances in the intestine [46]. Therefore, L. plantarum ATCC8014 might have a certain protective effect on the intestine-enhancing the intestinal barrier function and preventing AA from entering the body. Finally, some studies have shown that $L$. plantarum also has well-known antioxidant functions. In vitro, $L$. plantarum has an effective free radical scavenging ability and reducing ability $[47,48]$, and can enhance the antioxidant enzyme activity of Caco-2 cells [49]. In vivo, L. plantarum not only enhances the antioxidant status of the kidney [50], liver [47, 51], and heart [52], but also enhances the activity of antioxidant enzymes in the plasma of rats, and enhances the overall antioxidant level of rats [50]. Although the antioxidant activity of lactic acid bacteria has been confirmed by in vivo and in vitro tests, its specific antioxidant mechanism is not clear enough and needs further investigation. Some evidence suggests that $L$. plantarum may produce antioxidant substances, including polysaccharides, proteins, vitamins and glutathione [20], and the antioxidant enzymes contained in its own antioxidant system [53, 54]. The extensively studied exopolysaccharides have a strong ability to scavenge free radicals [55], and they can reduce the accumulation of lipid peroxides by stimulating the activity of antioxidant enzymes in mice, and ultimately reduce the oxidative stress in mice [56]. Therefore, L. plantarum ATCC8014 might produce polysaccharides, proteins and other substances, which can stimulate the antioxidant system of rats to enhance their own antioxidant capacity. At the same time, the antioxidant enzymes produced by the bacteria themselves also participate in the antioxidant process in rats. These antioxidant substances penetrate the intestinal epithelium, enter the bloodstream, and are dispersed throughout the body while targeting organs and tissues [57], which effectively reduces AA-induced toxicity in rats. 
According to our experimental results, the prevention group had a better alleviating effect than the therapeutic group. After our analysis, we concluded that the reasons for this might be that in the prevention group, L. plantarum ATCC8014 entered the intestine before AA stayed or colonized. These bacteria might have reduced absorption of AA by enhancing the intestinal barrier function. In addition, part of AA might be excreted by binding to bacteria forming complexes, thus further reducing the absorption of AA.

\section{Supplementary information}

Supplementary information accompanies this paper at https://doi. org/10.1186/s13765-020-00527-9.

Additional file 1. The appearance of rats in each group on the last day of experiment.

\section{Acknowledgements}

Not applicable.

\section{Authors' contributions}

The authors thank all of the study participants. All the participants conceived and designed the study; ZSJ and ZXD conducted experimentation on animals; JYJ, LYH and XHH guided all experiments; ZXD, FWX and LQB carried out all statistical analysis; ZSJ and SML completed the manuscript. All authors read and approved the final manuscript.

\section{Funding}

This work is supported by grants from National Natural Science Foundation of China (31801518), and the Young Creative Talents in Colleges of Heilongjiang Province (UNPYSCT-2016150).

\section{Availability of data and materials}

The datasets used and/or analyzed during the current study are available from the corresponding author on reasonable request.

\section{Competing interests}

The authors report no conflicts of interest.

\begin{abstract}
Author details
${ }^{1}$ College of Food Science, Northeast Agricultural University, Harbin 150030, China. ${ }^{2}$ Key Laboratory of Dairy Science, Ministry of Education, College of Food Science, Northeast Agricultural University, Harbin 150030, China. ${ }^{3}$ College of Veterinary Medicine, Northeast Agricultural University, Harbin 150030, China.
\end{abstract}

Received: 9 May 2020 Accepted: 27 July 2020

Published online: 06 August 2020

\section{References}

1. Abbes S, Ben Salah-Abbes J, Jebali R, Ben Younes R, Oueslati R (2016) Interaction of aflatoxin B-1 and fumonisin B-1 in mice causes immunotoxicity and oxidative stress: possible protective role using lactic acid bacteria. J Immunotoxicol 13(1):46-54. https://doi.org/10.3109/15476 91x.2014.997905

2. Markovic J, Stosic M, Kojic D, Matavulj M (2018) Effects of acrylamide on oxidant/antioxidant parameters and CYP2E1 expression in rat pancreatic endocrine cells. Acta Histochem 120(2):73-83. https://doi.org/10.1016/j. acthis.2017.12.001

3. Zhang L, Zhang H, Miao Y, Wu S, Ye H, Yuan Y (2012) Protective effect of allicin against acrylamide-induced hepatocyte damage in vitro and in vivo. Food Chem Toxicol 50(9):3306-3312. https://doi.org/10.1016/j. fct.2012.05.060

4. Esfahani BN, Kadivar M, Shahedi M, Soleimanian-Zad S (2017) Reduction of acrylamide in whole-wheat bread by combining lactobacilli and yeast fermentation. Food Addit Contamin Part 34(11):1904-1914. https://doi. org/10.1080/19440049.2017.1378444

5. Rivas-Jimenez L, Ramirez-Ortiz K, Gonzalez-Cordova AF, Vallejo-Cordoba B, Garcia HS, Hernandez-Mendoza A (2016) Evaluation of acrylamideremoving properties of two Lactobacillus strains under simulated gastrointestinal conditions using a dynamic system. Microbiol Res 190:19-26. https://doi.org/10.1016/j.micres.2016.04.016

6. Yildizbayrak N, Erkan M (2018) Acrylamide disrupts the steroidogenic pathway in Leydig cells: possible mechanism of action. Toxicol Environ Chem 100(2):235-246. https://doi.org/10.1080/02772248.2018.1458231

7. Chen S, Fan J, Zhang X (2009) The moderating role of dark soy sauce to acrylamide-induced oxidative stress and neurophysiological perturbations in rats. Toxicol Mech Methods 19(6-7):434-440. https://doi. org/10.1080/15376510903136895

8. Wei X, Yan F, Zhang C, Li G, Yang X, Zhang F, Wang S, Yu S (2015) Neuroprotective effect of Calpeptin on acrylamide-induced neuropathy in rats. Neurochem Res 40(11):2325-2332. https://doi.org/10.1007/s1106 4-015-1722-y

9. Bo L, Liu Y, Jia S, Liu Y, Zhang M, Li S, Zhao X, Sun C (2018) Metabonomics analysis of quercetin against the nephrotoxicity of acrylamide in rats. Food Funct 9(11):5965-5974. https://doi.org/10.1039/c8fo00902c

10. Cao C, Shi H, Zhang M, Bo L, Hu L, Li S, Chen S, Jia S, Liu YJ, Liu YL, Zhao X, Zhang $L$ (2018) Metabonomic analysis of toxic action of long-term lowlevel exposure to acrylamide in rat serum. Hum Exp Toxicol 37(12):12821292. https://doi.org/10.1177/0960327118769708

11. Nixon BJ, Stanger SJ, Nixon B, Roman SD (2012) Chronic exposure to acrylamide induces DNA damage in male germ cells of mice. Toxicol Sci 129(1):135-145. https://doi.org/10.1093/toxsci/kfs178

12. Abdel-Daim MM, Abd Eldaim MA, Hassan AGA (2015) Trigonella foenumgraecum ameliorates acrylamide-induced toxicity in rats: roles of oxidative stress, proinflammatory cytokines, and DNA damage. Biochem Cell Biol 93(3):192-198. https://doi.org/10.1139/bcb-2014-0122

13. Song J, Zhao M, Liu X, Zhu Y, Hu X, Chen F (2013) Protection of cyanidin-3-glucoside against oxidative stress induced by acrylamide in human MDA-MB-231 cells. Food Chem Toxicol 58:306-310. https://doi. org/10.1016/j.fct.2013.05.003

14. Anese M, Suman M, Nicoli MC (2010) Acrylamide removal from heated foods. Food Chem 119(2):791-794. https://doi.org/10.1016/j.foodc hem.2009.06.043

15. Serrano-Nino JC, Cavazos-Garduno A, Cantu-Cornelio F, GonzalezCordova AF, Vallejo-Cordoba B, Hernandez-Mendoza A, Garcia HS (2015) In vitro reduced availability of aflatoxin B-1 and acrylamide by bonding interactions with teichoic acids from lactobacillus strains. Lwt-Food Sci Technol 64(2):1334-1341. https://doi.org/10.1016/j.lwt.2015.07.015

16. Piotrowska M (2014) The adsorption of ochratoxin A by Lactobacillus species. Toxins 6(9):2826-2839. https://doi.org/10.3390/toxins6092826

17. El-Nezami H, Mykkanen H, Kankaanpaa P, Salminen S, Ahokas J (2000) Ability of Lactobacillus and Propionibacterium strains to remove aflatoxin B, from the chicken duodenum. J Food Prot 63(4):549-552. https://doi. org/10.4315/0362-028x-63.4.549

18. Fazeli MR, Hajimohammadali M, Moshkani A, Samadi N, Jamalifar H, Khoshayand MR, Vaghari E, Pouragahi S (2009) Aflatoxin B-1 binding capacity of autochthonous strains of lactic acid bacteria. J Food Prot 72(1):189-192. https://doi.org/10.4315/0362-028x-72.1.189

19. Wang L, Yue T, Yuan Y, Wang Z, Ye M, Cal R (2015) A new insight into the adsorption mechanism of patulin by the heat-inactive lactic acid bacteria cells. Food Control 50:104-110. https://doi.org/10.1016/j.foodc ont.2014.08.041

20. Aguilar-Toala JE, Astiazaran-Garcia H, Estrada-Montoya MC, Garcia HS, Vallejo-Cordoba B, Gonzalez-Cordova AF, Hernandez-Mendoza A (2019) Modulatory effect of the intracellular content of Lactobacillus casei CRL 431 against the aflatoxin B-1-induced oxidative stress in rats. Probiotics Antimicrob Proteins 11(2):470-477. https://doi.org/10.1007/s1260 2-018-9433-8

21. Allam NG, Ali EMM, Shabanna S, Abd-Elrahman E (2018) Protective efficacy of streptococcus thermophilus against acute cadmium toxicity in mice. Iran J Pharm Res 17(2):695-707 
22. Huang M, Jiao J, Wang J, Xia Z, Zhang Y (2018) Characterization of acrylamide-induced oxidative stress and cardiovascular toxicity in zebrafish embryos. J Hazard Mater 347:451-460. https://doi.org/10.1016/j.jhazm at.2018.01.016

23. Wu Z, Pan D, Guo Y, Zeng X (2013) Structure and anti-inflammatory capacity of peptidoglycan from Lactobacillus acidophilus in RAW-264.7 cells. Carbohydr Polym 96(2):466-473. https://doi.org/10.1016/j.carbp ol.2013.04.028

24. Zhang D, Liu W, Li L, Zhao H-Y, Sun H-Y, Meng M-H, Zhang S, Shao M-L (2017) Key role of peptidoglycan on acrylamide binding by lactic acid bacteria. Food Sci Biotechnol 26(1):271-277. https://doi.org/10.1007/ s10068-017-0036-Z

25. Shen Y, Zhao S, Zhao X, Sun H, Shao M, Xu H (2019) In vitro adsorption mechanism of acrylamide by lactic acid bacteria. Lwt-Food Sci Technol 100:119-125. https://doi.org/10.1016/j.lwt.2018.10.058

26. Kullisaar T, Songisepp E, Mikelsaar M, Zilmer K, Vihalemm T, Zilmer M (2003) Antioxidative probiotic fermented goats' milk decreases oxidative stress-mediated atherogenicity in human subjects. Br J Nutr 90(2):449-456. https://doi.org/10.1079/bjn2003896

27. Watterlot L, Rochat T, Sokol H, Cherbuy C, Bouloufa I, Lefevre F, Gratadoux J-J, Honvo-Hueto E, Chilmonczyk S, Blugeon S, Corthier G, Langella P, Bermudez-Humaran LG (2010) Intragastric administration of a superoxide dismutase-producing recombinant Lactobacillus casei BL23 strain attenuates DSS colitis in mice. Int J Food Microbiol 144(1):35-41. https://doi.org/10.1016/j.ijfoodmicro.2010.03.037

28. Bao W, Cao C, Li S, Bo L, Zhang M, Zhao X, Liu Y, Sun C (2017) Metabonomic analysis of quercetin against the toxicity of acrylamide in rat urine. Food Funct 8(3):1204-1214. https://doi.org/10.1039/c6fo01553k

29. Okesola MA, Ajiboye BO, Oyinloye BE, Ojo OA (2019) Neuromodulatory effects of ethyl acetate fraction of Zingiber officinale Roscoe extract in rats with lead-induced oxidative stress. J Integr Med 17(2):125-131. https://doi.org/10.1016/j.joim.2019.01.002

30. El-Beltagi HS, Ahmed MM (2016) Assessment the protective role of quercetin on acrylamide-induced oxidative stress in rats. J Food Biochem 40(6):715-723

31. Dobrowolski P, Huet P, Karlsson P, Eriksson S, Tomaszewska E, Gawron A, Pierzynowski SG (2012) Potato fiber protects the small intestinal wall against the toxic influence of acrylamide. Nutrition 28(4):428-435. https://doi.org/10.1016/j.nut.2011.10.002

32. Kovac R, Rajkovic V, Koledin I, Matavulj M (2015) Acrylamide alters glycogen content and enzyme activities in the liver of juvenile rat. Acta Histochem 117(8):712-717. https://doi.org/10.1016/j.acthis.2015.09.004

33. Esmaeelpanah E, Razavi BM, Hasani FV, Hosseinzadeh H (2018) Evaluation of epigallocatechin gallate and epicatechin gallate effects on acrylamide-induced neurotoxicity in rats and cytotoxicity in PC 12 cells. Drug Chem Toxicol 41(4):441-448. https://doi.org/10.1080/01480 545.2017 .1381108

34. Su B, Guan Q, Wang M, Liu N, Wei X, Wang S, Yang X, Jiang W, Xu M, Yu S (2018) Calpeptin is neuroprotective against acrylamide-induced neuropathy in rats. Toxicology 400:1-8. https://doi.org/10.1016/j. tox.2018.03.003

35. Mehri S, Shahi M, Razavi BM, Hassani FV, Hosseinzadeh H (2014) Neuroprotective effect of thymoquinone in acrylamide-induced neurotoxicity in Wistar rats. Iran J Basic Med Sci 17(12):1007-1011

36. Jiang GY, Zhang LL, Wang $H$, Chen $Q$, Wu XL, Yan XL, Chen Y, Xie MY (2018) Protective effects of a Ganoderma atrum polysaccharide against acrylamide induced oxidative damage via a mitochondria mediated intrinsic apoptotic pathway in IEC-6 cells. Food Funct 9(2):1133-1143. https://doi.org/10.1039/c7fo01619k

37. Zhu Y-J, Zeng T, Zhu Y-B, Yu S-F, Wang Q-S, Zhang L-P, Guo X, Xie $K-Q$ (2008) Effects of acrylamide on the nervous tissue antioxidant system and sciatic nerve electrophysiology in the rat. Neurochem Res 33(11):2310-2317. https://doi.org/10.1007/s1 1064-008-9730-9

38. LoPachin RM, Schwarcz Al, Gaughan CL, Mansukhani S, Das S (2004) In vivo and in vitro effects of acrylamide on synaptosomal neurotransmitter uptake and release. Neurotoxicology 25(3):349-363. https://doi. org/10.1016/s0161-813x(03)00149-9

39. Krishna G (2015) Inulin supplementation during gestation mitigates acrylamide-induced maternal and fetal brain oxidative dysfunctions and neurotoxicity in rats. Neurotoxicol Teratol 49:49-58. https://doi. org/10.1016/j.ntt.2015.03.003
40. Altinoz E, Turkoz Y, Vardi N (2015) The protective effect of N-acetylcysteine against acrylamide toxicity in liver and small and large intestine tissues. Bratis Med J Bratislavske Lekarske Listy 116(4):252-258. https://doi.org/10.4149/bll_2015_049

41. Boettcher MI, Bolt HM, Drexler H, Angerer J (2006) Excretion of mercapturic acids of acrylamide and glycidamide in human urine after single oral administration of deuterium-labelled acrylamide. Arch Toxicol 80(2):55-61. https://doi.org/10.1007/s00204-005-0011-y

42. Rajeh NA, Al-Dhaheri NM (2017) Antioxidant effect of vitamin E and 5-aminosalicylic acid on acrylamide induced kidney injury in rats. Saud Med J 38(2):132-137. https://doi.org/10.15537/smj.2017.2.16049

43. Gratz S, Taubel M, Juvonen RO, Viluksela M, Turner PC, Mykkanen $H$, El-Nezami H (2006) Lactobacillus rhamnosus strain GG modulates intestinal absorption, fecal excretion, and toxicity of aflatoxin B-1 in rats. Appl Environ Microbiol 72(11):7398-7400. https://doi.org/10.1128/ aem.01348-06

44. Anderson RC, Cookson AL, McNabb WC, Park Z, McCann MJ, Kelly WJ, Roy NC (2010) Lactobacillus plantarum MB452 enhances the function of the intestinal barrier by increasing the expression levels of genes involved in tight junction formation. BMC Microbiol. https://doi. org/10.1186/1471-2180-10-316

45. Karczewski J, Troost FJ, Konings I, Dekker J, Kleerebezem M, Brummer RJM, Wells JM (2010) Regulation of human epithelial tight junction proteins by Lactobacillus plantarum in vivo and protective effects on the epithelial barrier. Am J Physiol-Gastroint Liver Physiol 298(6):G851G859. https://doi.org/10.1152/ajpgi.00327.2009

46. Zhai QX, Tian FW, Zhao JX, Zhang H, Narbad A, Chen W (2016) Oral administration of probiotics inhibits absorption of the heavy metal cadmium by protecting the intestinal barrier. Appl Environ Microbiol 82(14):4429-4440. https://doi.org/10.1128/aem.00695-16

47. Banwo K, Alonge Z, Sanni Al (2020) Binding capacities and antioxidant activities of Lactobacillus plantarum and Pichia kudriavzevii against cadmium and lead toxicities. Biol Trace Element Res. https://doi. org/10.1007/s12011-020-02164-1

48. Lin XN, Xia YJ, Wang GQ, Yang YJ, Xiong ZQ, Lv F, Zhou W, Ai LZ (2018) Lactic acid bacteria with antioxidant activities alleviating oxidized oil induced hepatic injury in mice. Front Microbiol 9:10. https://doi, org/10.3389/fmicb.2018.02684

49. Hou G, Surhio MM, Ye H, Gao X, Ye Z, Li J, Ye M (2019) Protective effects of a Lachnum polysaccharide against liver and kidney injury induced by lead exposure in mice. Int J Biol Macromol 124:716-723. https://doi. org/10.1016/j.ijbiomac.2018.11.133

50. Korkmaz OA, Sadi G, Kocabas A, Yildirim OG, Sumlu E, Koca HB, Nalbantoglu B, Pektas MB, Akar F (2019) Lactobacillus helveticus and Lactobacillus plantarum modulate renal antioxidant status in a rat model of fructose-induced metabolic syndrome. Archiv Biol Sci 71(2):265-273. https://doi.org/10.2298/abs190123008k

51. Bouhafs L, Moudilou EN, Exbrayat JM, Lahouel M, Idoui T (2015) Protective effects of probiotic Lactobacillus plantarum BJ0021 on liver and kidney oxidative stress and apoptosis induced by endosulfan in pregnant rats. Ren Fail 37(8):1370-1378. https://doi.org/10.3109/08860 $22 \times .2015 .1073543$

52. Sefidgari-Abrasi S, Karimi P, Roshangar L, Morshedi M, Bavafa-Valenlia K, Saghafi-Asl M, Mohiti S, Rahimiyan-Heravan M (2020) Lactobacillus plantarum and inulin: therapeutic agents to enhance cardiac ob receptor expression and suppress cardiac apoptosis in type 2 diabetic rats. J Diabetes Res 2020:14. https://doi.org/10.1155/2020/4745389

53. Zuo F, Yu R, Feng X, Khaskheli GB, Chen L, Ma H, Chen S (2014) Combination of heterogeneous catalase and superoxide dismutase protects Bifidobacterium longum strain NCC2705 from oxidative stress. Appl Microbiol Biotechnol 98(17):7523-7534. https://doi.org/10.1007/s0025 3-014-5851-z

54. Arasu MV, Al-Dhabi NA, Rejiniemon TS, Lee KD, Huxley VAJ, Kim DH, Duraipandiyan V, Karuppiah P, Choi KC (2015) Identification and characterization of Lactobacillus brevis P68 with antifungal, antioxidant and probiotic functional properties. Indian J Microbiol 55(1):19-28. https:// doi.org/10.1007/s12088-014-0495-3

55. Bomfim VB, Neto J, Leite KS, Vieira ED, lacomini M, Silva CM, dos Santos KMO, Cardarelli HR (2020) Partial characterization and antioxidant activity of exopolysaccharides produced by Lactobacillus plantarum 
CNPC003. LWT-Food Sci Technol 127:8. https://doi.org/10.1016/j. Iwt.2020.109349

56. Zhang J, Zhao X, Jiang YY, Zhao W, Guo T, Cao YQ, Teng JW, Hao XN, Zhao J, Yang ZN (2017) Antioxidant status and gut microbiota change in an aging mouse model as influenced by exopolysaccharide produced by Lactobacillus plantarum YW11 isolated from Tibetan kefir. J Dairy Sci 100(8):6025-6041. https://doi.org/10.3168/jds.2016-12480

57. Annalisa N, Alessio T, Claudette TD, Erald V, Antonino DL, Nicola DD (2014) Gut microbioma population: an indicator really sensible to any change in age, diet, metabolic syndrome, and life-style. Mediators Inflamm. https://doi.org/10.1155/2014/901308

\section{Publisher's Note}

Springer Nature remains neutral with regard to jurisdictional claims in published maps and institutional affiliations.

\section{Submit your manuscript to a SpringerOpen ${ }^{\odot}$ journal and benefit from:}

- Convenient online submission

- Rigorous peer review

- Open access: articles freely available online

- High visibility within the field

- Retaining the copyright to your article

Submit your next manuscript at $\boldsymbol{\nabla}$ springeropen.com 